\title{
異なる作物上に打ける捕食性天敵スワルスキーカブリダニ (ダニ目：カブリダニ科）の定着と増殖の差異
}

\author{
柿元 一樹 ${ }^{1, *} \cdot$ 松比良 邦彦 $^{1} \cdot$ 井上 栄明 ${ }^{1} \cdot$ 伊藤 由香 ${ }^{2}$ \\ ${ }^{1}$ 鹿児島県農業開発総合センター \\ 2 鹿児島県南薩地域振興局農政普及課
}

\begin{abstract}
Differences in Establishment and Population Growth of the Predatory Mite Amblyseius swirskii (Acari: Phytoseiidae) on Different Commercial Crops. Kazuki Kakimoto, ${ }^{1, *}$ Kunihiko Matsuhira, ${ }^{1}$ Hideaki Inoue ${ }^{1}$ and Yuka Ito ${ }^{2}$ ${ }^{1}$ Kagoshima Prefectural Institute for Agricultural Development; Kinpou-cho, Minamisatsuma, Kagoshima 899-3401, Japan. ${ }^{2}$ Kagoshima Prefectural Nansatsu Regional Promotion Bureau Agricultural Promotion and Advisory Division; Juuni-cho, Ibusuki, Kagoshima 891-0403, Japan. Jpn. J. Appl. Entomol. Zool. 61: 223-232 (2017)

Abstract: Suitability of four commercial crops, sweet pepper, eggplant, kidney bean, and snap pea, against the predatory mite Amblyseius swirskii Athias-Henriot were evaluated from its establishment and population growth on each crop at $24^{\circ} \mathrm{C}$, suitability of their pollens as a food source, and effect of the phylloplane microscopic structure (presence and morphology of hairy tissue (trichomes and pubescence) and domatia). The number of mites after release per plant significantly differed among the crops, the density on sweet pepper was the highest, followed by kidney bean, eggplant, and snap pea. Based on the suitability of pollen for mites' oviposition rates, oviposition sites, and consumption against Thrips palmi Karny on each leaf disc, the causes of less population growth on kidney bean, eggplant, and snap pea in comparison to sweet pepper were considered to be as follows. (1) Kidney bean: lower suitability of pollen as food and unstable provision of pollen caused by flower's fluctuation on the plant. (2) Eggplant: lower suitability of pollen and the obstruction on mite's predation or oviposition behavior by sharp trichomes on phylloplane. (3) Snap pea: lack of phylloplane microscopic structure for oviposition sites and the obstruction on mite's predation or oviposition behavior by epicuticular wax on phylloplane.
\end{abstract}

Key words: Biological control; phytoseiids; IPM; pollen; domatia

緒

言

スワルスキーカブリダニAmblyseius swirskii Athias-Henriot は，アザミウマ類やコナジラミ類などに対する実用的な 捕食性天敵であり（Nomikou et al., 2001; Messelink et al., 2006; Wimmer et al., 2008; Arthurs et al., 2009; Calvo et al., 2011; Doğramaci et al., 2011), 鹿児島県では施設栽培の ピーマン Capsicum annuum L. やキュウリ Cucumis sativus L. での利用が普及している. アザミウマ類やコナジラミ 類などが発生する施設園芸に扔いて持続性の高い防除技術 を確立するためには，今後様々な作物においてスワルス キーカブリダニの実用性の評価および普及拡大に向けた技 術確立を図る必要がある。しかし，本県ではピーマンおよ びキュウリ以外の作物では一部の検証的導入に限定され, 本種の導入に先立ち実用性の検討を要する作物が多いのが
現状である. 本県での生産地における導入事例のうち, 冬 春期施設栽培のナス Solanum melongena L. やサヤインゲン Phaseolus vulgaris L. では，本種を放飼しても十分に定着が 確認できないことなどが生産地での課題となっているが, この要因を十分に考察，特定できていないことも普及に至 らない大きな要素である.

ある天敵を導入し，実用的効果が得られる作物とそうで ない作物では，対象害虫（餌）の量, 代替慨の存在および 量, 殺虫・殺菌剤の影響, 温度などの環境的影響, 摘葉な どの栽培技術に起因する天敵の生息場所の攪乱，寄主植 物 (作物) そのものに対する天敵の適応性などが異なると 考えられる。これらの影響を十分に考慮した上で，天敵の 定着および増殖を増強する手段の確立, 天敵の放飼量の決 定，導入する天敵種の選定が必要であると思われる。しか し，天敵の定着打よび増殖に関与する様々な要因の影響を

*E-mail: kakimoto-kazuki@pref.kagoshima.lg.jp

2017 年 3 月 17 日受領 (Received 17 March 2017)

2017 年 9 月 27 日登載決定 (Accepted 27 September 2017)

DOI: $10.1303 /$ jjaez.2017.223 
生産地围場において検証および考察することは極めて困難 である。

捕食性ダニ類をはじめとした天敵と植物との間には密 接な相互関係が存在することが知られている（Dicke and Sabelis, 1988；Schmidt, 2014)。具体的には，飭となる花 粉の影響打よび葉の微細構造 (毛状組織 (毛状突起や毛 じ）打よびそれと葉脈などから形成される domatia (Walter, 1996））の影響などである. しかし，花粉の慨としての適 性と葉の微細構造の両面から捕食性ダ二類の定着と増殖の 差異を検討した研究はほとんど見当たらない，そこで著者 らは，スワルスキーカブリダニが実用化に至っているピー マンと今後本種の利用が見込まれる作物として，ナス， サヤインゲンおよびスナップエンドゥ Pisum sativum ssp. hortense Asch.の 4 種作物を材料に, 花粉扰よび葉の微細 構造が本種の産卵または捕食量に及ぼす影響を調べること で，作物への定着と増殖に及ぼす主な要因について考察す るとともに，放飼実験によって各作物に対する本種の適応 性を明らかにした。 な打，葉面の微細構造がスワルスキー カブリダニの行動 (ここでは, 植物体葉面の把持または葉 面上での歩行）に影響を及ぼすなら，結果的に䬣探索効率 や捕食能力に影響し，捕食量の相違として発現されること が推察される. そこで，葉面の微細構造が本種の行動に及 ぼす影響を推し量るためのパラメータとして，本研究では 間接的ではあるが，各葉面に打けるミナミキイロアザミウ マ Thrips palmi Karny に対する本種の捕食量を用いて評価 した。 また，放飼実験は，スワルスキーカブリダニの増殖 量が餌となる害虫個体数打よび温度に影響を受けないよ う，それぞれの作物に本種の慨となりそうな節足動物類が 存在せず，本種の増殖に適した約 $24^{\circ} \mathrm{C}$ (Lee and Gillespie, 2011）の条件で実施した.

本文に先立ち，スワルスキーカブリダニの提供を賜った アリスタライフサイエンス (株)の山中 聡博士に厚く御礼 申し上げる。また，研究の実施にあたって貴重な意見を 賜った宮崎大学農学部の大野和朗博士, 農業・食品産業技 術総合研究機構九州沖縄農業研究センターの水谷信夫博 士，同西日本農業研究センターの安部順一朗博士，同野菜 花き研究部門の太田 泉博士, 同中央農業研究センターの 下田武志博士打よび日本典秀博士，石原産業(株)の森 光 太郎博士，統計処理にあたってご助言をいただいた農業・ 食品産業技術総合研究機構中央農業研究センターの光永貴 之博士に厚く御礼申し上げる。な招，本研究の一部は，そ れぞれ農林水産業・食品産業科学技術研究推進事業「登録 農薬の少ない地域特産作物（マイナー作物）に扔ける天敵 利用技術の確立 (27009B)」および「“いつでも天敵”～天 敵増殖資材による施設園芸の総合的害虫防除体系の確立・ 実証〜（26070C）」により実施したものである.
材料打よび方法

\section{1. 花粉がスワルスキーカブリダニの産卵に及ぼす影響}

ピーマン，ナス，サヤインゲン执よびスナップエンドゥ の各種の花粉がスワルスキーカブリダニの産卵数に及ぼす 影響を調べるため，それぞれの作物の葉面上において同一 作物の花粉を与え, 以下の方法により飼育実験を行った。 また当該実験においては，仮に作物の花粉が慨として適し ていても, 各葉面が産卵場所として適していなければ本種 が産卵しない可能性がある。そこで，本種の産卵場所とし て毛系を供試した.

供試虫には，アリスタライフサイエンス(株)の「スワル スキー『」を用いた。この製剤ボトルの中から交尾中のス ワルスキーカブリダニ雌雄成虫 1 対を無作為に選び，面 相筆を用いて後述する実験用の葉片へ移した，後述する 飼育方法によって絶食状態で 24 時間の交尾機会を設けた 後，雄成虫を除去し，雌成虫を実験に供した，実験は，後 藤・天野（1996）によるリーフディスク法に準じた。直径 $9 \mathrm{~cm} \times$ 高さ $3 \mathrm{~cm}$ のプラスチック製シャーレ, $4 \mathrm{~cm}$ 四方に 切除した作物の葉片および同一サイズの脱脂綿を用いた。 各作物は殺虫剤抢よび殺菌剤無散布の条件で屋外にて栽培 し, 各株の中位付近に位置する葉を採取した後, 所定の大 きさに調整して供試葉片を作製した．シャーレに脱脂綿 を敷いた後，供試葉片の葉裏を上にして脱脂綿上に重ね， シャーレには葉片の縁に接する高さまで水道水を注いで供 試虫の逃亡を防いだ。また, 対照区には植物の葉片の代わ りに $4 \mathrm{~cm}$ 四方に調整したプラスチックパラフィンフィル ム (パラフィルム ${ }^{\circledR}$; Bemis Flexible Packaging) を用いた.

花粉の供試にあたっては，各作物から開花中の花を採取 して他の節足動物が存在しないことを確認した後, 葉片上 に2 花分（但し，サヤインゲンは 3 花分）の萂を置いた。 雌成虫 10 個体を 7 日間個別飼育し, 飼育開始から 3 日, 5 日拈よび 7 日目に本種の生存, 産卵数および産卵場所を実 体顕微鏡下で観察した，供試虫への給水のために，脱脂綿 を直径約 $5 \mathrm{~mm}$ に丸め，水で湿らせたものを与えた。 なお， 対照区には水のみを与えた。供試虫の産卵場所として，長 さ $2 \mathrm{~cm}$ に調整した黒色の毛糸を置いた．産卵数の計数時 には，卵の産まれた場所を葉上，毛系または萂に分けて記 録するとともに，調査日毎に供試虫を新たな飼育装置へ移 動させることで, 葉片, 葯, 水打よび毛糸を交換した。実 験は温度 $25^{\circ} \mathrm{C}$ および光周期 $16 \mathrm{~L}: 8 \mathrm{D}$ の条件下で行った.

2. 葉面の微細構造がスワルスキーカブリダニの捕食量 に及ぼす影響

各作物に寄生可能なミナミキイロアザミウマを材料と し，本種の 2 齢幼虫に対するスワルスキーカブリダニの 3 日間の捕食量を温度 $25^{\circ} \mathrm{C}$ 打よび光周期 $16 \mathrm{~L}: 8 \mathrm{D}$ の条件下 で調べた。スワルスキーカブリダニの供試方法は上述の 1 
の実験に準じた。ミナミキイロアザミウマは，2012 年 4 月 に鹿児島県農業開発総合センターのピーマン戋場から採取 し, その後ソラマメVicia faba L. の催芽種子を用いて累代 飼育した個体群を用いた。予備実験により，上述の 1 で示 したリーフディスク法では一部の作物に扔いて供試虫のミ ナミキイロアザミウマが葉を離脱して水没することが確認 された，このため，当該実験では 3 枚のアクリル板を用い たマンジャーセル法（後藤・天野，1996）に準じて実施し た. 短辺 $5 \mathrm{~cm} \times$ 長辺 $10 \mathrm{~cm}$ 打よび厚さ $1 \mathrm{~cm}$ で中央に直径 $3 \mathrm{~cm}$ の穴を開けた厚型アクリル板打よび短辺 $5 \mathrm{~cm} \times$ 長辺 $10 \mathrm{~cm}$ で厚さが $0.3 \mathrm{~cm}$ の薄型アクリル板 2 枚を用い, 厚型 アクリル板を 2 枚の薄型アクリル板で挟むことで厚型アク リル板の高さ $1 \mathrm{~cm}$ および直径 $3 \mathrm{~cm}$ の範囲を飼育空間とし た。底面の薄型アクリル板には直径 $3 \mathrm{~cm}$ の穴をあけてこ こに目合い約 $25 \mu \mathrm{m}$ のゴースを張り通気口とした。まず, 底面用アクリル板の上に同形のろ紙を敷き，順に同形の供 試葉，厚型アクリル板，蓋用の薄型アクリル板を順に重ね 合わせた．短辺の双方はダブルクリップで固定した．蓋用 の薄型アクリル板には直径約 $2 \mathrm{~mm}$ の穴を開けて供試虫の 投入口とし，吸虫管を用いてミナミキイロアザミウマ 2 齢 幼虫 10 頭およびスワルスキーカブリダニ雌成虫 1 頭を放 飼した。供試虫の放飼後にこの投入口を長さ約 $1 \mathrm{~cm}$ に調 整した綿棒の先端でふさいだ。なお，本種雌成虫は，実験 供試前に 24 時間水のみを与え絶食状態とした。 反復は 10 個体とし, 実験開始から 24 時間毎に慨のミナミキイロア ザミウマの死亡個体数を実体顕微鏡下で観察するととも に，餌を全て交換しながら 3 日間調査を実施した。 スワル スキーカブリダニを放飼しない飼育装置も毎回 5 反復設 け，24 時間飼育した場合のミナミキイロアザミウマ 2 齢幼 虫の自然死亡個体数を観察した。

\section{3. 作物上におけるスワルスキーカブリダニの定着およ び増殖の比較}

(1) 実験条件

鹿児島県南さつま市金峰町の県農業開発総合センターの ガラス温室 $\left(\right.$ 約 $30 \mathrm{~m}^{2}$ ) に扔いて, ピーマン (品種：「TM 鈴波」; タキイ種苗(株)) , ナス (品種：「筑陽」; タキイ種 苗(株)), サヤインゲン (品種 :「ベストクロップキセラ」; 雪印種苗(株)）打よびスナップエンドウ（品種：「ニムラ サラダスナップ」; みかど協和(株)）の 4 種作物をポット栽 培し, 2015 年 5 月 8 日から 6 月 5 日まで放飼実験を実施し た. 各作物の空間サイズに違いが生じないよう，ピーマン およびナスは 1 ポットに 1 株を，サヤインゲンおよびス ナップエンドウは 1 ポットに 3 株を $1 / 2,000 \mathrm{a}$ のプラスチッ ク製ワグナーポット（「ワグネルポット」; 藤本科学工業 (株)；以下，ポットと略）に植え，この 1 ポットを 1 反復 としてそれぞれの作物毎に 3 反復を設けた。 ポットは，約 $1.5 \mathrm{~m}$ の間隔を設けて温室内にランダムに配置した.
作物の開花開始時期を揃えるため，ピーマンおよびナス は 2015 年 3 月 18 日, サヤインゲンおよびスナップエンド ウは 2015 年 4 月 2 日に播種し, その後常温のガラス温室 で育苗した。 ピーマンおよびナスは, 128 穴のセルトレイ に播種し, 14 日後の 2015 年 4 月 2 日に直径 $12 \mathrm{~cm}$ のビニ ルポットに鉢上げした後, 2015 年 5 月 4 日まで 36 日間育 苗した。両作物の最初の花が開花した頃 (2015 年 5 月 4 日) に，育苗培土 (タキイ種苗(株) ) を充填したポットへ移植 した。一方，サヤインゲン打よびスナップエンドウは, ピーマンおよびナスを植えたものと同一のポットの中央部 3 か所へ，植穴間の距離を $15 \mathrm{~cm}$ として 1 か所当たり 1 粒 ずつを播種した，供試したポットには，試験開始の直前お よび試験開始から 14 日後に, 1 ポット当たり $30 \mathrm{~g}$ の粒状 化成肥料（N:P:K=15:15:15）を施用した。灌水は，スワ ルスキーカブリダニへの影響を避けるため植物体を直接濡 らさぬよう留意しながら毎日行った。 また, 各作物には直 径約 $1 \mathrm{~cm}$ ，長さ $180 \mathrm{~cm}$ の支柱を添えた。温度データにつ いては, 温度データロガー（「抢んどとり Jr. TR-52i」; (株) ティアンドデイ)を用いて 1 時間間隔で計測した。温室内 の湿度は計測しなかったが，実験期間中に過度に乾燥しな いように 1 日に 2 回温室内の床面に散水し湿度を保持した。

（2）供試虫打よび放飼方法

スワルスキーカブリダニは，アリスタライフサイエンス

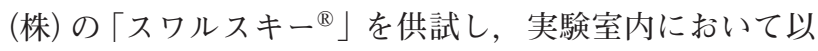
下の手順により供試虫を採集した。すすなお，製刋ボトル 内に封入された緩衝材を振り出した後, 先端に $1 \mathrm{ml}$ 容量 のプラスチック製チップを取り付けた吸虫管を用いて, 歩 行する個体を成虫打よび幼若虫を区別せずにランダムに 50 頭採集した。1 本のチップに 50 頭を収容し，このチッ プを供試作物の株元に静置した。本種のポット間移動を防 ぐため，ポット底面に近い側面に粘着性のポリブテン（ポ リオレフィン系樹脂) 剤 (「ハエトリ粘着剤エアゾール」; (株)ニッソーグリーン) を塗布した.

\section{(3) 調查方法}

1 ポットを 1 株とみなし，各作物の株全体に生息するス ワルスキーカブリダニの成虫, 幼若虫および卵を作物の 葉，茎，花打よび果実または萊の 4 部位に分けて株毎に目 視により計数した. 計数に当たっては本種の成虫および幼 若虫の発育態は区別しなかった。調査は，放飼日（2015 年 5 月 8 日）から $3,7,14,21,28$ 日後に実施した。 また, 調査 日毎に各作物の代表的な 1 ポットの植物体の花数を計数し た，花弁が脱落するまでは花としてみなした，果実または 萊については，収穫による虫の持ち出しを避けるため，果 実または萊に本種の生息が認められた場合にはこれらを 供試株の株元に静置することで元の株への移動を促した. これらの果実または萊については，3 日後に本種が生息し ないことを確認してから取り除いた。さらに，本種の定 
着および増殖の考察に資するため，茎頂部から 4 ないし 5 節目の展開葉を採取し，葉の微細構造を電子顕微鏡（「VE8800 」; $\operatorname{KEYENCE}($ 株) ) にて 50 倍の条件下で検鏡した。

\section{4. 統計処理}

各作物の花粉または水を与えた場合の 7 日当たりのスワ ルスキーカブリダニの産卵数, ミナミキイロアザミウマ 2 齢幼虫に対する 3 日間の捕食量は，産卵数または捕食量を 応答変数, 作物の違いを説明変数として一元配置分散分析 により解析した後, Tukeyの HSD 検定により各水準間の 有意差を検出した。作物の花粉または水を与えた場合の 7 日間の産卵場所については, 1 個体当たりの総産卵数を $N$, 葉上に産まれた卵数を $Y$ ，それ以外の場所に産まれた卵数 を $N-Y$ とし，葉上に産まれた卵数の割合 $Y / N$ を応答变数， 餌の違いを説明変数とし，5種類の餌のそれぞれの組み合 わせについて $G$ 検定を行った. ただし，この処理にあたっ ては 10 通りの対比較であったため，危険率 $p$ 值 $(0.05)$ を Holm 法により補正した。

異なる作物上に打けるスワルスキーカブリダニの個体数 を比較するため, 本種の 1 株当たり全個体数を応答変数, 作物の種類 (固定効果) 打よび調査日 (変量効果) を説明変 数とする二元配置分散分析 (混合モデル) により解析した. 応答変数については Box-Cox 変換により等分散正規分布 へ近似し, 反復測定因子である調查日は変量効果として設 定した。事後検定として，調査日毎にそれぞれの水準間の 有意差を Tukeyの HSD 検定により比較した。ただし，こ の際危険率 $p$ 值は 0.05 を調查回数 5 回で除した 0.01 とし て設定した。な打，統計処理にあたっては，JMP12（SAS Institute, 2015）を用いた.

(a) Oviposition numbers

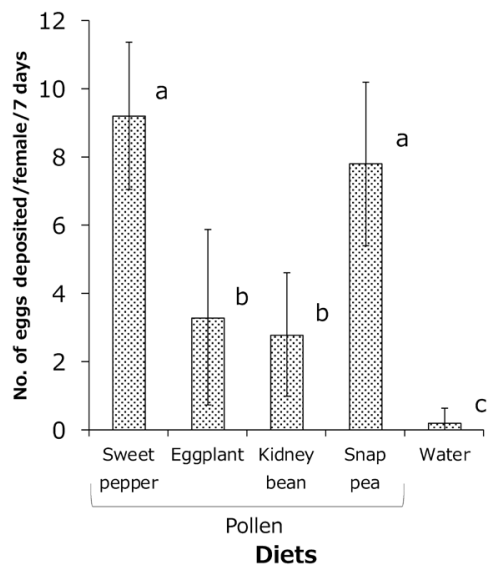

結

果

1. 花粉がスワルスキーカブリダニの産卵に及ぼす影響

ピーマン，ナス，サヤインゲンおよびスナップエンドウ の 4 種の葉面に打いて各作物の花粉を与えた場合，スワ ルスキーカブリダニの産卵数は有意に異なった（Fig. 1a； ANOVA : $F=33.9, \mathrm{df}=4, p<0.01)$. ピーマンおよびスナッ プエンドウの花粉を与えた場合, 7 日間当たりの本種の 1 雌当たり産卵数はピーマンで 9.2 卵，スナップエンドウで 7.8 卵であり，この 2 作物間では有意な差は認められず (Tukeyの HSD 検定, $p>0.05$ ), ナスおよびサヤインゲン の花粉を与えた場合に比べて有意に多かった（Tukeyの HSD 検定， $p<0.05)$ ．一方，ナス拈よびサヤインゲンでの産卵 数はそれぞれ 3.3 卵および 2.8 卵で，これら 2 作物間では 相互に有意差は認められなかった（Tukeyの HSD 検定, $p>$ $0.05)$ 。水のみを与えた場合には本種の産卵はほとんど認 められず (0.2 卵)，どの作物の花粉を与えた場合の産卵数 よりも有意に少なかった（Tukeyの HSD 検定, $p<0.05)$.

ピーマン，ナスおよびサヤインゲン葉のディスク上では, それぞれ 39.8\%，24.2\% 打よび 46.6\% の卵が葉面に産まれて おり，残りの卵はほとんどが毛糸で確認された (Fig. 1b)。 な お，これら 3 作物葉面での産卵場所はほとんどが葉脈の基 部や葉脈間の分岐部, 毛状突起の先端部であった。 これに 対し，スナップエンドウの葉面上执よびプラスチックフィ ルム上での産卵場所は，先の 3 作物とは大きく異なり，こ の両者のディスク上では卵は全く確認されず，ほとんどの 卵が産卵場所として置いた毛系に産まれていた。ピーマン， ナスおよびサヤインゲンの葉面上に産まれた卵の割合は相 互に有意な差は認められなかった $(G$ 検定, $p>0.025)$.

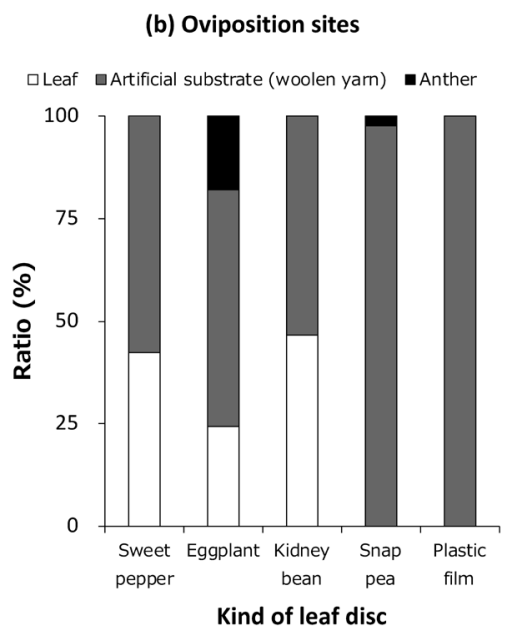

Fig. 1. (a) Number of ovipositions in seven days laid by Amblyseius swirskii provided with different diets (mean $\pm \mathrm{SD}$ ). (b) Oviposition sites of $A$. swirskii on the different leaf discs. The same small letters indicate non-significant differences of the oviposition numbers among the diets (Tukey-HSD test, $p>0.05$ ). 
方，スナップエンドウ葉面上での産卵割合は，プラスチッ クフィルムとの間に有意な差はなかったが $(G$ 検定, $p>$ 0.05)，ピーマン，ナスおよびサヤインゲンに比べて有意 に低かった $(G$ 検定, $p<0.006)$.

\section{2. 葉面の微細構造がスワルスキーカブリダニの捕食量} に及ぼす影響

マンジャーセル法により実施した各作物葉面でのスワル スキーカブリダニの捕食量を Fig. 2 に示す. 本種を放飼し ない各作物でのミナミキイロアザミウマ 2 齢幼虫の死亡率 は毎回 $5 \%$ 未満であったため，ミナミキイロアザミウマ幼 虫の死亡は全てスワルスキーカブリダニによる捕食による ものとみなした

本種の捕食量は作物間で有意に異なった (Fig. 2; ANOVA： $F=30.80, \mathrm{df}=3, p<0.01)$. ピーマン打よびサヤインゲン 上での捕食量は，3 日間でそれ朰れ 8.4 頭および 8.2 頭で あり，これら 2 種類間では有意な差は認められなかった (Tukeyの HSD 検定， $p>0.05$ )。一方，ナス打よびスナッ プエンドゥでの捕食量はそれれぞれ 4.0 頭打よび 2.4 頭であ り，これら 2 作物上での捕食量は相互に有意な差は認めら れなかったが (Tukeyの HSD 検定, $p>0.05$ )，ピーマンお よびサヤインゲン上での捕食量に比べると有意に少なかっ た (Tukeyの HSD 検定, $p<0.05$ ).

3. 放飼実験時の温度変化および供試植物の生育変化な らびに形態観察

放飼実験期間中の施設内温度は，開始から 7 日間および 以後 7 日間隔でそれぞれ平均 $23.7^{\circ} \mathrm{C}, 23.4^{\circ} \mathrm{C}, 24.0^{\circ} \mathrm{C}, 24.4^{\circ} \mathrm{C}$ で，期間中平均は $23.8^{\circ} \mathrm{C}$ であった。

作物の花数の変化は作物間で異なり（Fig. 3), ピーマン 扣よびナスの花数は時間の経過とともに連続的に増加した が，サヤインゲンおよびスナップエンドウの花数には異な る変動が認められた。すなわち，これらの作物の花数はス

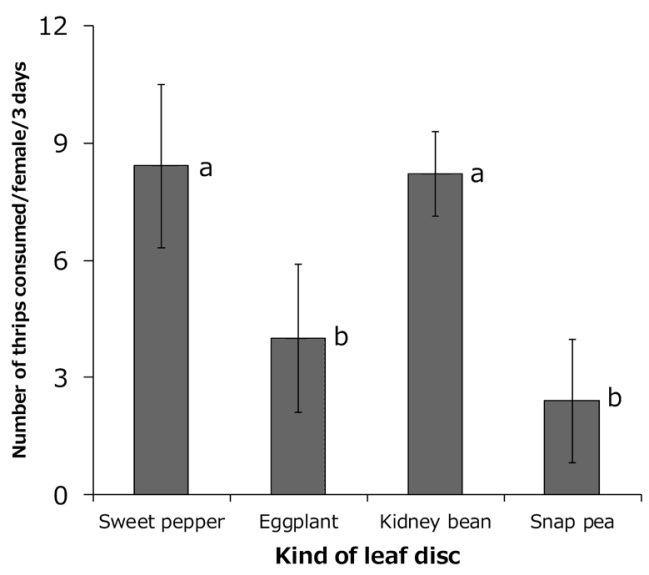

Fig. 2. Consumed number of 2nd instar larvae of Thrips palmi by A. swirskii on the four different leaf discs $($ mean $\pm \mathrm{SD})$. The same small letters indicate non-significant differences of the predation rates among the leaf discs (Tukey-HSD test, $p>0.05$ ).
ワルスキーカブリダニの放飼から 7 日後または 14 日後に いったん大きく減少し, 28 日後に再び増加するパターンで あつた。

Fig. 4 は，葉面の微細構造を電子顕微鏡（50 倍）にて撮 影した結果である。ピーマン（Fig. 4a）では長形の無腺毛 状突起と短形の有腺毛状突起 (Adedeji et al., 2007), ナス (Fig. 4b) では鋭利な放射状無腺毛状突起と短形の無腺毛 状突起 (Adedeji et al., 2007) が確認された. サヤインゲン (Fig. 4c) では無腺毛状突起が確認されたが，スナップエ ンドウ (Fig. 4d) では毛状突起は全く確認されなかった. ピーマン，ナスおよびサヤインゲンの 3 作物では，明瞭な 葉脈の隆起が確認されたのに対し，スナップエンドウでは 葉脈の隆起も極めて小さかった.

4. 作物上におけるスワルスキーカブリダニの定着およ び増殖の比較

スワルスキーカブリダニの定着状況は供試した 4 種作物 間で異なり，個体数の差は放飼 21 日後以降大きくなった (Fig. 5)。なお，各作物上においては，調査期間中本種の 餌となりうる節足動物類は観察されなかった.

ピーマン (Fig. 5a), ナス (Fig. 5b) およびサヤインゲン (Fig. 5c) に打けるスワルスキーカブリダニ個体数は，成・ 幼若虫および卵ともに時間の経過とともに増加した。放 飼 3 日後には，成・幼若虫はいずれの作物上でも約 18 頭 であり，卵は認められなかったが，放飼 28 日後の成・幼 若虫数打よび卵数は，ピーマンでそれぞれ 518.3 頭打よび 342.3 個，ナスで 81.0 頭打よび 60.0 個，サヤインゲンで 350.0 頭および 157.3 個であった. 放飼個体数 (50 頭/株) に対する 28 日後の全ステージ合計個体数を基準とした場 合の増殖程度は，ピーマンでは約 17 倍，ナスでは約 2.8 倍, サヤインゲンでは約 10 倍であった. 一方，スナップエン ドウ（Fig. 5d）に打ける本種の個体数は大きく増加するこ となく推移し，放飼 28 日後の成・幼若虫数打よび卵数は それぞれ 27.3 頭打よび卵で 4.7 個であり，全ステージ合計 個体数は放飼個体数よりも減少した.

スワルスキーカブリダニの成・幼若虫および卵までを含

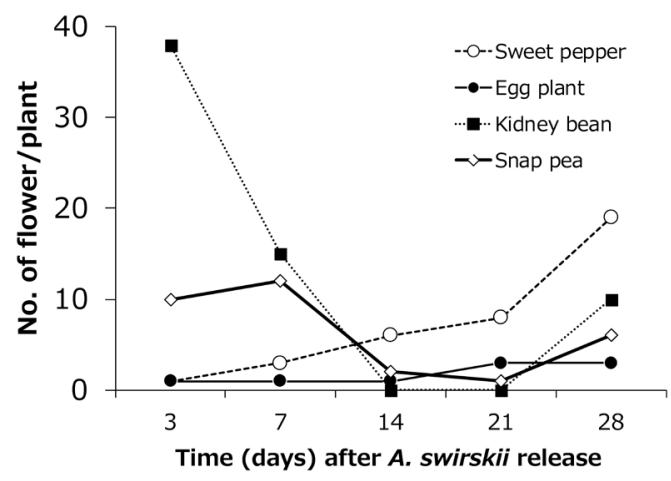

Fig. 3. Changes in time (days) of flower on four crops. 

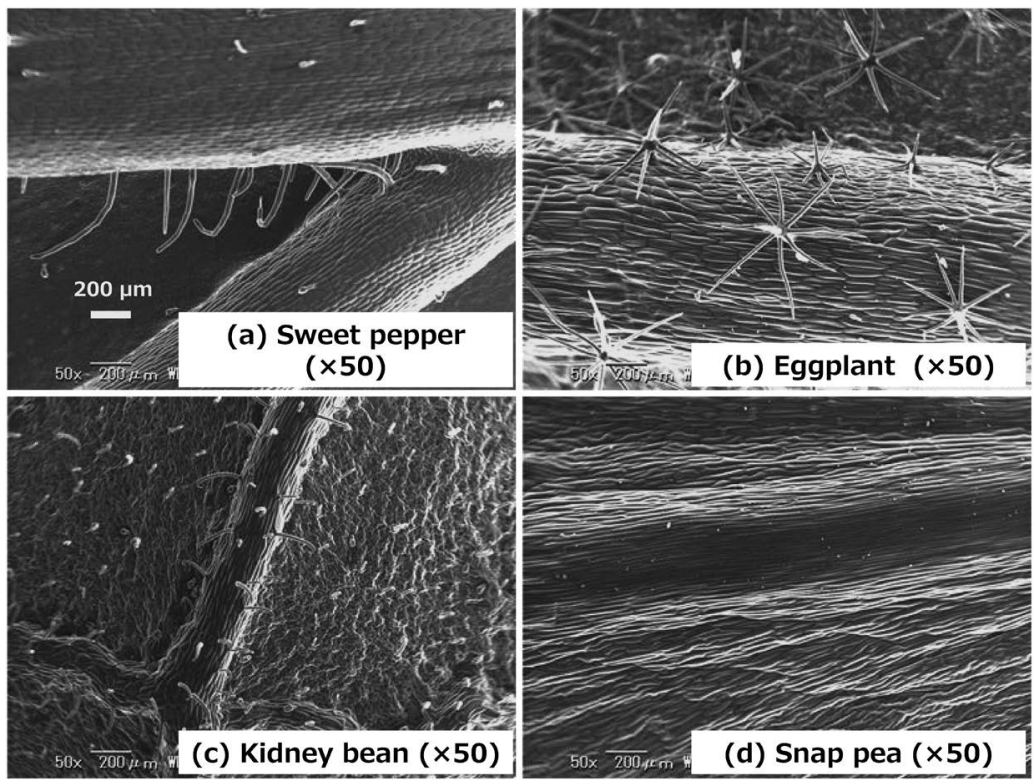

Fig. 4. Electronic microscope scanning of the leaf surface in four crops: (a) sweet pepper, (b) eggplant, (c) kidney bean, and (d) snap pea.

(a) Sweet pepper

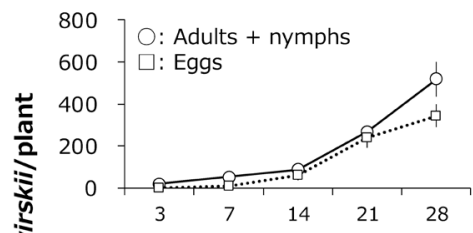

(c) Kidney bean

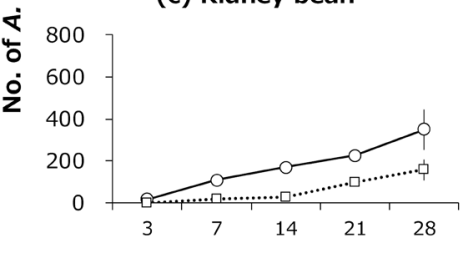

Time (days) after $A$. swirskii release (b) Eggplant

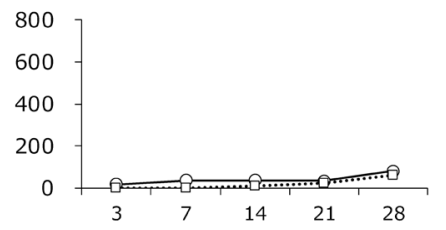

(d) Snap pea

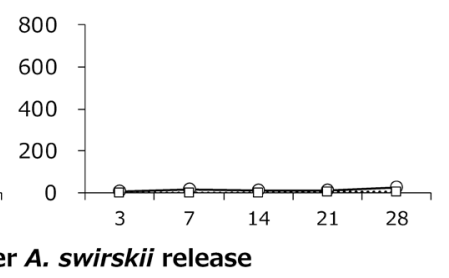

Fig. 5. Changes in time (days) of $A$. swirskii population densities (mean $\pm \mathrm{SD}$ ) on four crops: (a) sweet pepper, (b) eggplant, (c) kidney bean, and (d) snap pea.

Table 1. ANOVA for the effects of plant species on the population densities of $A$. swirskii ${ }^{\mathrm{a}}$

\begin{tabular}{lrccc}
\hline \multicolumn{1}{c}{ Factors } & df & Mean square & $F$-value & $p$-value \\
\hline Plant species (Fixed effect) & 3 & 72001.8 & 90.06 & $<0.0001$ \\
Time (Random effect) & 4 & 45103.5 & 56.42 & $<0.0001$ \\
Error & 52 & 799.5 & & \\
\hline
\end{tabular}

${ }^{\mathrm{a}}$ Data were transformed by Box-Cox transformation before ANOVA.

めた全ステージの株当たり個体数は，作物の種類により有 意に異なった（Table 1)。調查日毎に各作物上の本種個体 数を Tukeyの HSD 検定により比較すると，時間の経過と ともに作物間での差は大きくなった. 放飼 3 日後では作物
間に有意な差は認められなかったが $(p>0.01)$, 放飼 7 日 後ではサヤインゲンで他の作物に比べて有意に多く $(p<$ 0.01)，スナップエンドゥでは他の 3 作物に比べて有意に 少なかった $(p<0.01)$. 放飼 14 日後では, ピーマンおよ びサヤインゲンの両者に有意な差はなく $(p>0.01)$, いず れもナスおよびスナップエンドウに比べて有意に多かった $(p<0.01)$ ．なお，ナス拉よびスナップエンドウでの個体 数に有意な差はなかった $(p>0.01)$. 放飼 21〜28 日後で は，ピーマンでの個体数が他の 3 作物に比べて有意に多く $(p<0.01)$, 次いでサヤインゲンで多かった. ナスおよび スナップエンドゥでの個体数は有意な差はなく $(p>0.01)$, い ずれもサヤインゲンより有意に少なかった $(p<0.01)$. 
$\square$ Leaf Branch $\square$ Flower $\square$ Fruit or pod

(a) Sweet pepper

(Adults+Nymphs)

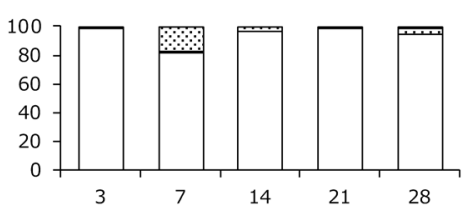

(c) Eggplant

(Adults+Nymphs)

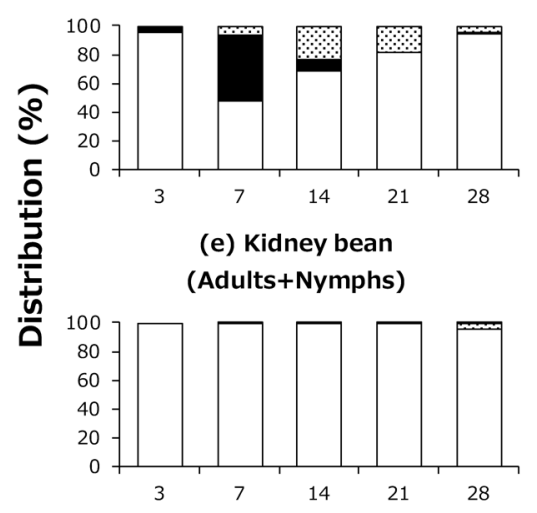

(g) Snap pea

(Adults+Nymphs)

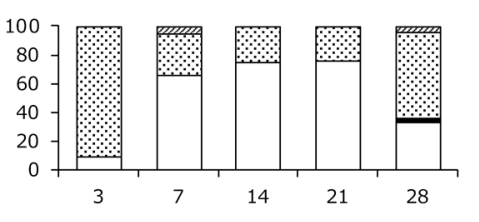

Time (days) after $\boldsymbol{A}$. swirskii release (b) Sweet pepper (Eggs)

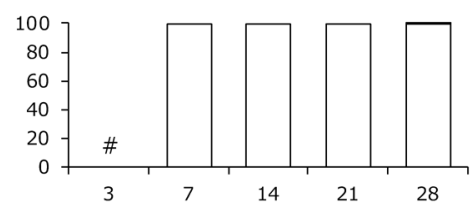

(d) Eggplant

(Eggs)

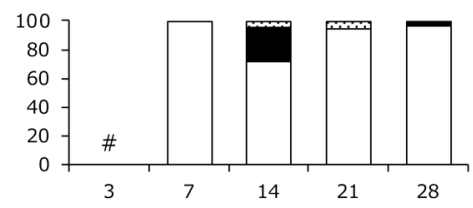

(f) Kidney bean

(Eggs)

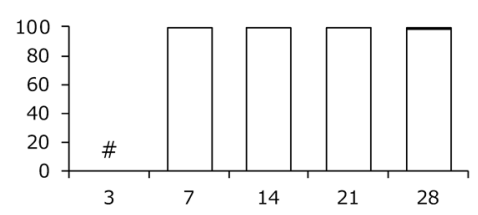

(h) Snap pea

(Eggs)

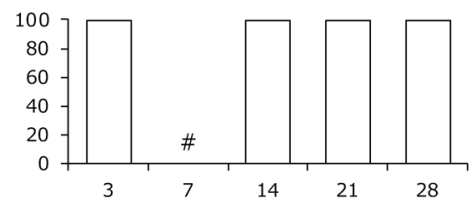

Fig. 6. Distribution of A. swirskii on each part: leaf, branch, flower, and fruit/pod of four crops: (a), (b) sweet pepper, (c), (d) eggplant, (e), (f) kidney bean, (g), (h) snap pea. \#: Eggs of A. swirskii were not observed on the plants.

\section{5. 作物上でのスワルスキーカブリダニの株内分布}

Fig. 6 は，各作物上のスワルスキーカブリダニの成· 幼若虫打よび卵の株当たり個体数に占める作物の各部位 (葉，茎，花打よび果実または萊) での個体数の割合であ る. ナス (Fig. 6c，d）では一時的に茎での分布割合が高 まった時期があったものの，ピーマン（Fig. 6a，b）打よ びサヤインゲン（Fig. 6e, f) を含むこれらの3 作物に打い ては，総じて葉での分布が主体であった。 これに対して スナップエンドゥ（Fig. 6g，h）での分布は大きく異なり， 成. 幼若虫の分布変化は花数の変動（Fig. 1）に同調し, 放飼 3 日後にはほとんどの個体が花で確認されたが（約 $91 \%)$ ，以後時間の経過とともに低下し，放飼 28 日後に再 び増加が認められた (約 60\%)。一方，卵については試験 期間を通じて終始全ての個体が葉で認められた。ただし， これは全て葉柄と小葉の分岐部であり，葉面上での卵は全 く確認されなかった.
考察

植物の花粉は，スワルスキーカブリダニの餌資源とし て重要であり (Swirski et al., 1967; Nomikou et al., 2001; Ali and Zaher, 2007; Avery et al., 2014), ナッメヤシ Phoenix dactylifera L. の花粉は, トウゴマ Ricinus communis L.より も慨として好適である (Ali and Zaher, 2007) など，本種の 発育と増殖は植物の花粉によって異なることが知られてい る. 本研究で 4 種作物の花粉を供試した結果, 本種の 7 日 間当たりの産卵数 (Fig. 1) は花粉の種類によって有意に異 なり，ピーマンおよびスナップエンドウの花粉を供試した 場合にはサヤインゲンとナスの花粉を与えた場合に比べて 有意に多かった。この結果から, 各作物上での本種の定着 と増殖に及ぼす 1 つ要因として，餌となる花粉の影響が 考えられた。

スワルスキーカブリダニに対するピーマンおよびスナッ プエンドウの花粉の適性は同等と推察されたが，スナッ 
プエンドゥの葉面上における本種の産卵場所は他の作物 とは大きく異なり，卵はスナップエンドウの葉面ではな く，ほとんどが毛糸に産まれていた（Fig. 1b)。 また，放 飼実験に打いては，本種の卵はスナップエンドウの複葉で わずかに確認されたものの，産卵場所は葉面上ではなく 全て葉柄と単葉の分岐部であった. Rasmy and El-Banhawy （1974）は，捕食性ダニ類の 1 種である Phytoseius plumifer （Canestrini and Fanzago）を用いた実験で，豊富な毛じが 存在するイチジク Ficus carica L. と平滑なサワーオレン ジ Citrus aurantium L.の葉面上に扔いて，本種の餙である Tetranychus cinnabarinus (Boisd.) を与えると, P. plumifer の 産卵数と捕食量はサワーオレンジに打いて少ないことを示 している. しかし，この要因については未解明のままであ る. 葉面の微細構造のうち, 毛状組織や domatia は捕食性 ダニ類の採餌場所, 生息空間の拡大による共食いの回避, 上位捕食者からの捕食や不適環境を回避するためのシェル ターとなるため，捕食性ダニ類の生存率打よび増殖率の向 上につながると考えられて打り（Dicke and Sabelis，1988； Schmidt, 2014), その存在によりスワルスキーカブリダニ を含む複数の捕食性ダニ類の植物への定着個体数が高ま ることが多く報告されている (Agrawal, 1997; Kreiter et al., 2003; Loughner et al., 2010; Avery et al., 2014; Bresch et al., 2015)。一方，スナップエンドウの葉面は平滑であり，毛 状組織打よび domatia は確認されなかった (Fig. 4d)。すすな わち, 自然状態のスナップエンドウ葉面ではスワルスキー カブリダニの産卵場所が欠落しているものと推察された.

他方，毛状突起は，昆虫・ダ二類に対する物理的障壁， 毒素による化学的影響打よび粘着様しゅん出物質による 捕捉などを通じて負の影響を及ぼすことが報告されてい る (Duffey, 1986; Gregory et al., 1986; Glas et al., 2012)。例 えば，ペラルゴニウム Pelargonium domesticum Bailey およ びゼラニウム $P$. hortorum Bailey の毛状突起は，オンシッ コナジラミ Trialeurodes vaporariorum (Westwood) の産卵 場所選択打よび産卵数に影響を及ぼすことが報告されてい る (Avery et al., 2015)。また, Dicke and Sabelis (1988) は トマトで見られるような有腺毛状突起は有毒で粘着性のあ るしゅん出物により捕食性ダニ類に対して悪影響を及ぼす ことを論じている．チリカブリダニPhytoseiulus persimilis Athias-Henriot (Van Haren et al., 1987) やリモニカスカブリ ダニAmblydromalus limonicus (Garman and McGregor) (Van Houten et al., 2013) では, トマトの有腺毛状突起からの しゅん出物がこれらの捕食性ダニ類を捕捉することで死亡 率が高まり，トマト上での天敵の増殖や防除効果が低下す ることが報告されている.

本報告では，葉面の微細構造がスワルスキーカブリダニ の行動へ及ぼす影響を知るため，ミナミキイロアザミウマ に対する本種の捕食量を検討した。ナス抢よびスナップエ
ンドウ葉面上での捕食量は，ピーマンおよびサヤインゲ ンに比べて有意に少なかった (Fig. 2). いずれの作物でも トマトのような粘着性物質をしゅん出する有腺毛状突起 は確認されなかったが，ナスでは葉面を覆う多数の鋭利 な放射状無腺毛状突起 (Adedeji et al., 2007) が確認された (Fig. 4b). 毛状突起の形状や量が捕食性ダニ類に及ぼす影 響はこれまでに報告されていない。しかし，コナジラミ類 に対する寄生蜂の 1 種であるオンシツッヤコバチ Encarsia formosa Gahanの歩行速度は, 毛状突起の多い植物ほど遅 く，寄主探索の妨げになることが示されている（HulspasJordaan and van Lenteren, 1978). また, Lit and Bernardo （1990）は，ナスの鋭利な毛状突起はヨコバイの 1 種であ る Amrasca biguttula (Ishida) の吸汁打よび産卵を妨げるこ とを明らかにしている。一方，スナップエンドウの葉面 には第一級アルコール類を成分とするエピクチクラワッ クスが存在することが知られて抢り (Jeffree, 1986)，この ワックスは昆虫の歩行を妨げる効果があると報告されて いる (Woodhead and Chapman, 1986). Eigenbrode and Jetter (2002) は，キャベツ Brassica oleracea L.のエピクチクラ ワックス結晶体が，捕食者である Hippodamia convergens Guérin-Méneville の足を滑らせて葉面の把持を妨げるため, 本種の定着性の低下に影響する主な要因であることを明ら かにしている．また，同著者はこれと同様の作用はエン ドウの 1 種に扔いても見られると論じている (Eigenbrode and Jetter, 2002).これらのことから，本実験においては， ナスでは葉面上の鋭利な毛状突起が，スナップエンドウで はエピクチクラワックスがスワルスキーカブリダニの行動 を妨げ，このことで䭒探索効率が低下した，あるいは捕食 行動そのものが悪影響を受けたことなどにより本種の捕食 量が少なくなった可能性がある.

以上のことを総合的に判断すると，スワルスキーカブリ ダニの定着と増殖に及ぼす各作物の影響とその要因につい ては以下のと打り推察される. 本種の個体数が最も多かっ たピーマンは，餌としての花粉の適性打よび葉面の微細構 造の面から本種に最も適した作物であると考えられる。 こ れに対して，サヤインゲンでの個体数がピーマンに比べて 少なかったのは，花粉の適性がピーマンよりも低いことに 加え，本作物では花数が変動していたため（Fig. 3)，飭で ある花粉の量が不安定であったことが挙げられる。一方, ナスでは，餌としての花粉の適性が低いこと，鋭利な毛状 突起が本種の捕食行動に悪影響を及ぼしたと同様に葉での 産卵行動などにも悪影響を及ぼした可能性が考えられる。 スナップエンドウの花粉の適性はピーマンと同等であると 考えられたが，放飼実験に打ける個体数は最も少なかっ た。これは，本種の産卵場所として重要な微細構造が欠落 していること，植物体表面を覆うエピクチクラワックスが 本種の捕食行動や産卵行動などに悪影響を及ぼした可能性 
が考えられる，な报，本報告では，各葉面上でのミナミキ イロアザミウマに対するスワルスキーカブリダニの捕食量 に基づき，微細構造やエピクチクラワックスが本種の行動 に及ぼす影響を考察した。しかし，これらの結果だけで作 物上での本種の定着および増殖に及ぼす影響を完全に説明 することは難しい．これらの要因が本種の捕食行動以外の どのような行動を妨げるのかは今後の解明が必要である. ナス打よびスナップエンドウでは，本種の分布位置もピー マン拉よびサヤインゲンとはやや異なり，ナスでは時期に よっては茎での分布割合が増加し，スナップエンドウでは 花での分布割合が特徴的に他の作物よりも高かった。この ことは，葉の微細構造と何らかの関係があるかもしれない。

害虫の発生前あるいは少発生時から天敵を導入する接種 的放飼法 (Van Driesche and Bellows, Jr., 1996; Hajek, 2004) では，放飼後の天敵の定着と増殖が重要と考えられる。本 報告での実験結果に基づくと，生産地圃場での実用にあ たってサヤインゲンおよびナスのように作物の花粉が餌と して適さない作物では，スワルスキーカブリダニの増殖を 促すための代替慨の人為的な供給も検討する必要がある. また，スナップエンドゥのように葉の微細構造が欠落して いたり，エピクチクラワックスを持つ作物では，本種の定 着および増殖場所を提供するような技術も視野に入れるべ きであると考えられる。

摘要

ピーマン，ナス，サヤインゲンおよびスナップエンドウ の 4 種作物に対するスワルスキーカブリダニの適応性を, 作物での定着と増殖の相違, 花粉の適性, 葉面の微細構造 (毛状組織 (毛状突起や毛じ) および domatia) の観点から評 価した。平均 $24^{\circ} \mathrm{C}$ の条件下で本種を放飼した結果，本種 個体数は作物間で有意に異なり, ピーマン, サヤインゲン, ナス，スナップエンドウの順に多かった．各作物の花粉を 与えた場合の産卵数, 葉面上での産卵場所拉よびミナミキ イロアザミウマに対する捕食量から，ピーマンに比べてサ ヤインゲン，ナスおよびスナップエンドウでの増殖が劣る 要因として以下のことが推察された。（1）サヤインゲン： 餌としての花粉の適性が低いこと，および作物上での花粉 の量が不安定であること.（2）ナス：花粉の適性が低いこ と，打よび葉面に存在する鋭利な毛状突起が本種の捕食行 動や産卵行動に影響すること。（3）スナップエンドウ：葉 面の微細構造が欠落していること，および葉のエピクチク ラワックスが本種の捕食行動や産卵行動に影響すること.

\section{引用文 献}

Adedeji, O., O. Y. Ajuwon and O. O. Babawale (2007) Foliar epidermal studies, organographic distribution and taxonomic importance of trichomes in the family solanaceae. Int. J. Botany 3: 276-282. Agrawal, A. (1997) Do leaf domatia mediate a plant-mite mutualism? An experimental test of the effects on predators and herbivores. Ecol. Entomol. 22: 371-376.

Ali, F. S. and M. A. Zaher (2007) Effect of food and temperature on the biology of Typhlodrompis swirskii (Athias-Henriot) (Acari: Phytoseiidae). Acarines 1: 17-21.

Arthurs, S., C. L. McKenzie, J. J. Chen, M. Dogramaci, M. Brennan, K. Houben and L. Osborne (2009) Evaluation of Neoseiulus cucumeris and Amblyseius swirskii (Acari: Phytoseiidae) as biological control agents of chilli thrips, Scirtothrips dorsalis (Thysanoptera: Thripidae) on pepper. Biol. Control 49: 91-96.

Avery, P. B., V. Kumar, Y. F. Xiao, C. A. Powell, C. L. McKenzie and L. S. Osborne (2014) Selecting an ornamental pepper banker plant for Amblyseius swirskii in floriculture crops. Arthropod Plant Interact. 8: 49-56.

Avery, P. B., V. Kumar, M. S. J. Simmons and J. Faull (2015) Influence of leaf type and density on the host plant selection by the greenhouse whitefly, Trialeurodes vaporariorum (Hemiptera: Aleyrodidae). Appl. Entomol. Zool. 50: 79-87.

Bresch, C., G. Ruiz, C. Poncet and P. Parolin (2015) Predatory mites Neoseiulus californicus and Phytoseiulus persimilis chose plants with domatia. JME 13: 13-20.

Calvo, F. J., K. Bolckmans and J. E. Belda (2011) Control of Bemisia tabaci and Frankliniella occidentalis in cucumber by Amblyseius swirskii. BioControl 56: 185-192.

Dicke, M. and M. W. Sabelis (1988) How plants obtain predatory mites as bodyguards. Neth. J. Zool. 38: 148-165.

Doğramaci, M., S. P. Arthurs, J. J. Chen, C. McKenzie, F. Irrizary and L. Osborne (2011) Management of chilli thrips Scirtothrips dorsalis (Thysanoptera: Thripidae) on peppers by Amblyseius swirskii (Acari: Phytoseiidae) and Orius insidiosus (Hemiptera: Anthocoridae). Biol. Control 59: 340-347.

Duffey, S. S. (1986) Plant glandular trichomes: their partial role in defence against insects. In Insects and the Plant Surface (B. Juniper and S. R. Southwood, eds.). Edward Arnold Ltd., London, pp. 151-172.

Eigenbrode, S. D. and R. Jetter (2002) Attachment to plant surface waxes by an insect predator. Integr. Comp. Biol. 42: 1091-1099.

Glas, J. J., B. C. J. Schimmel, J. M. Alba, R. Escobar-Bravo, R. C. Schuurink and M. R. Kant (2012) Plant glandular trichomes as targets for breeding or engineering of resistance to herbivores. Int. J. Mol. Sci. 13: 17077-17103.

後藤哲雄・天野 洋 (1996) 飼育法. 植物ダ二学 (江原昭三・真 梶徳純 編). 全国農村教育協会, 東京, pp. 314-322. [Gotoh, T. and H. Amano (1996) Rearing method. In Principles of Plant Acarology (S. Ehara and H. Amano, eds.). Zenkoku Nouson Kyouiku Kyoukai, Tokyo, pp. 314-322.

Gregory, P., D. A. Avé, P. Y. Bouthyette and W. M. Tingey (1986) Insect-defensive chemistry of potato glandular trichomes. In Insects and the Plant Surface (B. Juniper and S. R. Southwood, eds.) . Edward Arnold Ltd., London, pp. 173-183.

Hajek, A. (2004) Natural Enemies: An Introduction to Biological Control. Cambridge University Press, Cambridge. 378 pp. 
Hulspas-Jordaan, P. M. and J. C. van Lenteren (1978) The relationship between host plant leaf structure and parasitization efficiency of the parasitic wasp Encarsia formosa Gahan (Hymenoptera: Aphelinidae). Med. Fac. Landbouww. Rijksuniv. Gent. 43(2): 431-440.

Jeffree, C. E. (1986) The cuticle, epicuticular waxes and trichomes of plants, with reference to their structure, functions and evolution. In Insects and the Plant Surface (B. Juniper and S. R. Southwood, eds.) . Edward Arnold Ltd., London, pp. 23-64.

Kreiter, S., M.-S. Tixier and T. Bourgeois (2003) Do generalist phytoseiid mites (Gamasida: Phytoseiidae) have interactions with their host plants? Insect Sci. Appl. 23: 35-50.

Lee, H. S. and D. R. Gillespie (2011) Life tables and development of Amblyseius swirskii (Acari: Phytoseiidae) at different temperatures. Exp. Appl. Acarol. 53: 17-27.

Lit, M. C. and E. N. Bernardo (1990) Mechanism of resistance of eggplant (Solanum melongena Linn.) to the cotton leafhopper, Amrasca biguttula (Ishida) II. Morphological and biochemical factors associated with resistance. Philipp. J. Crop Sci. 15: 79-84.

Loughner, R., K. Wentworth, G. Loeb and J. Nyrop (2010) Influence of leaf trichomes on predatory mite density and distribution in plant assemblages and implications for biological control. Biol. Control 54: 255-262.

Messelink, G. J., S. E. F. van Steenpaal and P. M. J. Ramakers (2006) Evaluation of phytoseiid predators for control of western flower thrips on greenhouse cucumber. BioControl 51: 753-768.

Nomikou, M., A. Janssen, R. Schraag and M. W. Sabelis (2001) Phytoseiid predators as potential biological control agents for Bemisia tabaci. Exp. Appl. Acarol. 25: 271-291.

Rasmy, A. H. and E. M. El-Banhawy (1974) Behaviour and bionomics of the predatory mite, Phytoseius plumifer (Acarina:
Phytoseiidae) as affected by physical surface features of host plants. Entomophaga 19: 255-257.

SAS Institute (2015) JMP Statistics and Graphics Guide, version 12. SAS Institute, Cary, NC.

Schmidt, R. A. (2014) Leaf structures affect predatory mites (Acari: Phytoseiidae) and biological control: a review. Exp. Appl. Acarol. 62: 1-17.

Swirski, E., S. Amitai and N. Dorzia (1967) Laboratory studies on the feeding, development and reproduction of the predaceous mites Amblyseius rubini Swirski and Amblyseius swirskii Athias (Acarina: Phytoseiidae) on various kinds of food substances. Isr. J. Agric. Res. 17: 101-119.

Van Driesche, R. G. and T. S. Bellows, Jr. (1996) Biological Control. Chapman \& Hall, New York. 539 pp.

Van Haren, R. J. F., M. M. Steenhuis, M. W. Sabelis and O. M. B. De Ponti (1987) Tomato stem trichomes and dispersal success of Phytoseiulus persimilis relative to its prey Tetranychus urticae. Exp. Appl. Acarol. 3: 115-121.

Van Houten, Y. M. et al. (2013) Herbivory-associated degradation of tomato trichomes and its impact on biological control of Aculops lycopersici. Exp. Appl. Acarol. 60: 127-138.

Walter, D. E. (1996) Living on leaves: mites, tomentia, and leaf domatia. Annu. Rev. Entomol. 41: 101-104.

Wimmer, D., D. Hoffmann and P. Schausberger (2008) Prey suitability of western flower thrips, Frankliniella occidentalis, and onion thrips, Thrips tabaci, for the predatory mite Amblyseius swirskii. Biocontrol Sci. Technol. 18: 533-542.

Woodhead, S. and R. F. Chapman (1986) Insect behavior and the chemistry of plant surface waxes. In Insects and the Plant Surface (B. Juniper and S. R. Southwood, eds.). Edward Arnold Ltd., London, pp. 123-135. 